\title{
Roles of Oral Bacteria in Cardiovascular Diseases - From Molecular Mechanisms to Clinical Cases: Preface
}

\author{
Kazuo Umemura ${ }^{1, *}$ and Koichiro Wada ${ }^{2}$ \\ ${ }^{1}$ Department of Pharmacology, Hamamatsu University School of Medicine, Hamamatsu 431-3192, Japan \\ ${ }^{2}$ Department of Pharmacology, Graduate School of Dentistry, Osaka University, Suita 565-0871, Japan
}

Received December 7, 2009; Accepted December 24, 2009

Keywords: oral bacteria, cardiovascular disease, Porphyromonas gingivalis, Streptococcus mutans

Recent studies provide an epidemiological association between oral bacteria and cardiovascular diseases (1). The bacteria are gaining increasing attention for their likely association with cardiovascular diseases. This assertion is supported by several recent epidemiological studies that strongly indicated the involvement of oral bacteria in the development of atherosclerosis as well as aneurysms $(2,3)$. Possible mechanisms by which oral bacteria might contribute to cardiovascular disease have not come forth. However, within the confines of periodontal tissues, various bacteria and their antigens may initiate inflammatory responses with systemic consequences that could relate to cardiovascular diseases (4, 5). Alternatively, direct oral-hematogenous spreading of bacteria to cardiovascular tissues may also occur. Bacteremia is a common condition often associated with tooth brushing and dental treatment $(6-8)$. For example, Porphyromonas gingivalis, which is resistant to complement-mediated killing, is known to be able to survive within the bloodstream $(9,10)$, and recent in vitro and in vivo studies have suggested that the bacterium possesses several properties possibly related to the pathogenesis of atherosclerosis $(11,12)$.

Recently, editors' consensus in the American Journal of Cardiology and Journal of Periodontology indicated that periodontitis independently increases cardiovascular disease risks (13). Accordingly, it is recommended that patients with moderate to severe periodontitis should be informed that they carry an additional risk for atherosclerotic vascular disease associated with periodontitis. Be-

*Corresponding author. umemura@hama-med.ac.jp Published online in J-STAGE on May 24, 2010 (in advance) doi: 10.1254.jphs.09R27FM fore this consensus was published, we held a symposium to review the relationship between oral bacteria and the risk of cardiovascular diseases at the 82nd Annual Meeting of The Japanese Pharmacological Society, Yokohama, $15-17$ March, 2009. The review articles appearing here were presented at this symposium.

The aims of this JPS Forum Minireview series are to present recent findings about the mechanism through which oral bacteria may cause cardiovascular diseases and to suggest new therapeutic options for this complication.

The present review series contains "Implication of periodontal diseases in development of systemic diseases" by H. Inaba and A. Amano (14), "Porphyromonas gingivalis is the important role of intimal hyperplasia in the aorta" by K. Hokamura and K. Umemura (15), "Involvement of Porphyromonas gingivalis in the development of human aortic aneurysm" by K. Wada and Y. Kamisaki (16), "Cell-surface structures of novel serotype $k$ Streptococcus mutans strains and their correlation to virulence" by K. Nakano et al. (17), and "Treatment of periodontal disease regarded as biofilm infection: systemic administration of azithromycin" by P.-L. Wang (18).

We hope that this JSP Forum Minireview contributes to the development of new therapeutic strategies for cardiovascular diseases caused by oral bacteria.

\section{References}

1 Meurman JH, Sanz M, Janket SJ. Oral health, atherosclerosis, and cardiovascular disease. Crit Rev Oral Biol Med. 2004; 15:403-413.

2 Scannapieco FA, Bush BB, Paju S. Associations between periodontal disease and risk for atherosclerosis, cardiovascular dis- 
ease, and stroke. A systematic review. Ann Periodontol. 2003; 8:38-53.

3 D'Aiuto F, Parkar M, Andreaou G, Brett PM, Ready D, Tonetti MS. Periodontitis and atherogenesis: causal association or simple coincidence? J Clin Periodontol. 2004;31:402-411.

4 Beck J, Garcia R, Heiss G, Vokonas PS, Offenbacher S. Periodontal disease and cardiovascular disease. J Periodontol. 1996; 67:1123-1137.

5 Garcia RI, Henshaw MM, Krall EA. Relationship between periodontal disease and systemic health. Periodontol 2000. 2001; 25:21-36.

6 Kinane DF, Riggo MP, Walker KF, MacKenzie D, Shearer B. Bacteraemia following periodontal procedures. J Clin Periodontol. 2005;32:708-713.

7 Lockhart PB, Brennan MT, Sasser HC, Fox PC, Paster BJ, Bahrani-Mougeot FK. Bacteremia associated with toothbrushing and dental extraction. Circulation. 2008;17:3118-3125.

8 Perez-Chaparro PJ, Gracieux P, Lafaurie GI, Donnio PY, Bonnaure-Mallet M. Genotypic characterization of Porphyromonas gingivalis isolated from subgingival plaque and blood sample in positive bacteremia subjects with periodontitis. J Clin Periodontol. 2008;35:748-753.

9 Slaney JM, Gallagher A, Aduse-Opoku J, Pell K, Curtis MA. Mechanisms of resistance of Porphyromonas gingivalis to killing by serum complement. Infect Immun. 2006;74:5352-5361.

10 Potempa M, Potempa J, Okroj M, Popadiak K, Eick S, Nguyen $\mathrm{KA}$, et al. Binding of complement inhibitor C4bbinding protein contributes to serum resistance of Porphyromonas gingivalis. J Immunol. 2008;181:5537-5544.

11 Kuramitsu HK, Qi M, Kang IC, Chen W. Role for periodontal bacteria in cardiovascular diseases. Ann Periodontol. 2001;6:
41-47.

12 Li L, Messas E, Batista Jr EL, Levine RA, Amar S. Porphyromonas gingivalis infection accelerates the progression of atherosclerosis in a heterozygous apolipoprotein E-deficient murine model. Circulation. 2002;105:861-867.

13 Friedewald VE, Kornman KS, Beck JD, Genco R, Goldfine A, et al. The American Journal of Cardiology and Journal of Periodontology Editors' consensus: periodontitis and atherosclerotic cardiovascular disease. Am J Cardiol. 2009;104:59-68.

14 Inaba $\mathrm{H}$, Amano A. Roles of oral bacteria in cardiovascular diseases - from molecular mechanisms to clinical cases: Implication of periodontal diseases in development of systemic diseases. J Pharmacol Sci. 2010;113:103-109.

15 Hokamura K, Umemura K. Roles of oral bacteria in cardiovascular diseases - from molecular mechanisms to clinical cases: Porphyromonas gingivalis is the important role of intimal hyperplasia in the aorta. J Pharmacol Sci. 2010;113:110-114.

16 Wada K, Kamisaki Y. Roles of oral bacteria in cardiovascular diseases - from molecular mechanisms to clinical cases: Involvement of Porphyromonas gingivalis in the development of human aortic aneurysm. J Pharmacol Sci. 2010;113:115-119.

17 Nakano K, Nomura R, Matsumoto M, Ooshima T. Roles of oral bacteria in cardiovascular diseases - from molecular mechanisms to clinical cases: Cell-surface structures of novel serotype $k$ Streptococcus mutans strains and their correlation to virulence. J Pharmacol Sci. 2010;113:120-125.

18 Wang P-L. Roles of oral bacteria in cardiovascular diseases from molecular mechanisms to clinical cases: Treatment of periodontal disease regarded as biofilm infection: systemic administration of azithromycin. J Pharmacol Sci. 2010;113:126-133. 